\title{
Delineation of groundwater potential zones using remote sensing, GIS, and AHP techniques in southern region of Banjarnegara, Central Java, Indonesia
}

Rilo Restu Surya Atmaja, Doni Prakasa Eka Putra, Lucas Donny Setijadji

Rilo Restu Surya Atmaja, Doni Prakasa Eka Putra, Lucas Donny Setijadji, "Delineation of groundwater potential zones using remote sensing, GIS, and AHP techniques in southern region of Banjarnegara, Central Java, Indonesia," Proc. SPIE 11311, Sixth Geoinformation Science Symposium, 1131100 (21 November 2019); doi: 10.1117/12.2548473

EDIE Event: Sixth Geoinformation Science Symposium, 2019, Yogyakarta, Indonesia 


\title{
Delineation of Groundwater Potential Zones Using Remote Sensing, GIS, and AHP Techniques in the Southern Region of Banjarnegara, Central Java, Indonesia
}

\author{
Rilo Restu Surya Atmaja*a, Doni Prakasa Eka Putra ${ }^{a}$, Lucas Donny Setijadji ${ }^{a}$ \\ ${ }^{a}$ Department of Geological Engineering, Faculty of Engineering, Universitas Gadjah Mada, \\ Yogyakarta, Indonesia;
}

\begin{abstract}
Southern region of Banjarnegara Regency, Central Java, Indonesia have been experiencing water scarcity throughout dry season every year due to meteorological and geological condition. Meteorological drought in dry season have been recorded since 1984. About 85,000 people are affected. Local authorities were forced to send clean water aid routinely. This study aim to delineate groundwater potential zones using remote sensing, Geographical Information System (GIS), and Analytic Hierarchy Process (AHP). This study evaluate groundwater potential zones using 5 factors involving lineament, lithology, slope, drainage, and rainfall. Digital Elevation Model (DEM) from DEMNAS (published by Indonesian Geospatial Agency) was used to generate lineament delineation and slope map. Hydrography data provided by Indonesian Geospatial Agency was used to generate drainage density. Geological maps which were generated from remote sensing interpretation were provided from Geological Survey Center of Indonesia. Rainfall data were provided by BPS-Statistics of Banjarnegara. 52 springs and 2 bore wells data were used for result validation. All 5 thematic layers were prepared in GIS. All factors and its classes were assigned weights using AHP techniques and normalization of weights was conducted through the AHP. Groundwater potential zones map were generated, the results was classified into five zones as very high, high, moderate, low, and very low. The zones covered of $1.02 \mathrm{~km}^{2}(1.18 \%), 14.49 \mathrm{~km}^{2}$ (16.80\%), $33.65 \mathrm{~km}^{2}(38.99 \%), 37.12 \mathrm{~km}^{2}(43.02 \%)$, and $1529 \mathrm{~m}^{2}(0.00 \%)$ of study area respectively. Result validation by comparing the AHP map values with discharge of springs and bore wells showed promising result.
\end{abstract}

Keywords: groundwater potential zones, AHP, GIS, remote sensing, Banjarnegara, Indonesia

\section{INTRODUCTION}

Banjarnegara is located in the central part of Central Java, Indonesia. According to various reports, southern area of Banjarnegara encountered drought and clean water scarcity throughout the dry season in $2017^{123456}$. Local authorities had to send clean water aid to the community routinely. Drought happened not only in 2017, southern region of Banjarnegara have been experiencing meteorological drought since 1984. The peak of dry to very dry condition occur on August until November every year ${ }^{7}$.

Based on hydrogeological condition, southern region of Banjarnegara is a region without exploitable groundwater ${ }^{8}$. It correspond with its geological condition which mainly consist of igneous rocks, metamorphic rocks, and mélange ${ }^{9} 10$. Those rocks assemblages have low permeability ${ }^{8}$. Furthermore, southern region of Banjarnegara is considered as non groundwater basin area ${ }^{11}$. Therefore, various factors are responsible for drought and clean water scarcity in southern region of Banjarnegara including rainfall, geological condition, and unfavorable topographic condition.

About 85,000 people live in 18 villages in southern region of Banjarnegara 12131415 . They have been encountering drought and clean water scarcity in dry season every year. Those huge amount of affected people encourage to execute a mitigation effort and propose solutions. This study aim to delineate groundwater potential zones in the hard rock terrain of southern region of Banjarnegera, Indonesia using remote sensing, Geographical Information System (GIS), and Analytic Hierarchy Process (AHP). The map can be used as prospective guide for groundwater exploration and exploitation to fulfill community's need for clean water.

*rilo.restu.s@mail.ugm.ac.id

Sixth Geoinformation Science Symposium, edited by Sandy Budi Wibowo, Andi B. Rimba

Stuart Phinn, Ammar A. Aziz, Proc. of SPIE, Vol. 11311, 1131100 - (c) 2019 SPIE

CCC code: $0277-786 \mathrm{X} / 19 / \$ 21 \cdot$ doi: $10.1117 / 12.2548473$ 
Application of remote sensing which is combined with GIS can increase the accuracy of result in delineation of groundwater potential zone and also to reduce bias on any single theme ${ }^{16}$.

Integration of RS and GIS is an effective tools in terms of cost and time for assessing and managing groundwater

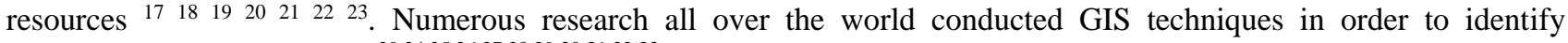
groundwater potential zones 2024252627282930313233 .

In recent years, the evaluation of groundwater potential zones is conducted using Multi Criteria Decision Analysis (MCDA). One of the most effective and most used MCDA method is AHP method. AHP provide mathematical objectivity to process subjective preference which is inevitable from individual or group in decision making. In principal, AHP works by developing priorities for alternatives and criteria which is used to evaluate alternatives ${ }^{34} 35$. Integration of GIS and AHP method have been successfully applied to delineate groundwater potential zones by numerous research ${ }^{36}$ 373839 with promising results. Furthermore, this research considered lineament, slope, rainfall, lithology, and drainage as influential factors of groundwater resources in hard rock geology condition. However, the weights and the employed thematic data were adjusted based on the investigated study area.

Finally, this study utilized RS, GIS, and AHP techniques as an integration to evaluate groundwater potential zones in southern region of Banjarnegara, Central Java, Indonesia. Evaluation and recognition of groundwater potential could guide the decision makers in groundwater exploration and exploitation to fulfill community's need for clean water.

\section{STUDY AREA}

The study area is located in the southern region of Banjarnegara regency, Central Java, Indonesia. Administratively, the study area consist of 18 villages which is distributed in 4 sub-districts. The study area is limited on hydrogeological unit of region without exploitable groundwater ${ }^{8}$. The study area covered an area of $115.89 \mathrm{~km}^{2}$. It is located between $109^{0}$ $30^{\prime}$ and $109^{\circ} 45^{\prime}$ East Longitude and $7^{\circ} 26^{\prime}$ and $7^{0} 31.5^{\prime}$ South Latitude (Figure 1). Therefore the climate of study area is tropical. Average annual rainfall from 2010 to 2017 is $4436 \mathrm{~mm} / \mathrm{year}$. Humidity is ranging from $71.3 \%$ to $91.3 \%$. While annual temperature is ranging from $20.8{ }^{\circ} \mathrm{C}$ to $27.2{ }^{\circ} \mathrm{C}$.

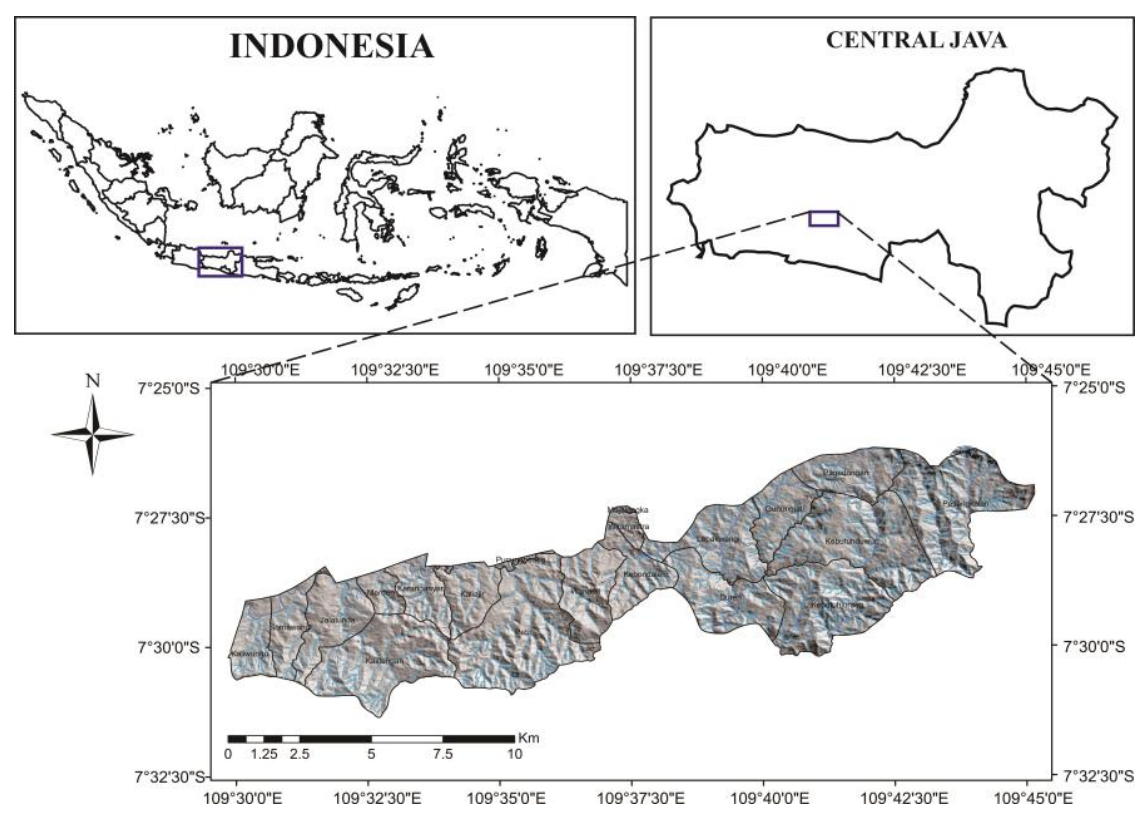

Figure 1. Location of the study area

The study area belongs to physiographical zone of South Serayu Mountains ${ }^{40}$. Geological maps in the scale of 1:50,000 informs that study area consist of 5 tectonites, 4 rock formations, and 2 quaternary deposits ${ }^{41}{ }^{42}$. The tectonites including Mélange Luk Ulo Complex, Serpentinite, Mafic and Ultramafic, Brecciated Rocks, and Greywacke. The rock formations comprise of Claystone Totogan Formation, Tuff Waturanda Formation, Sandstone Waturanda Formation. Then, 
quaternary deposit comprise of Sand Terrace Deposits and Alluvium ${ }^{41}{ }^{42}$. Furthermore, there are three main geological structure patterns in the study area including northeast-southwest (NE-SW), northwest-southeast (NW-SE), and east northeast-west southwest (ENE-WSW) 43445 .

\section{METHODS}

\subsection{Factors influencing groundwater potential}

To evaluate groundwater potential zones, five parameters: lineament, slope, rainfall, slope, and drainage were selected as the influential factors. Groundwater resource and occurrence is believed to be influenced and largely depended on those factors. The comprehensive research methods of the groundwater potential evaluation is shown in Figure 2.

Lineaments occur as straight, curvilinear, parallel or en-echelon features. Lineaments may represent fracture systems, discontinuity planes, faults, and shear zone in rocks. Lineaments can be identified on satellite images ${ }^{46}$. Lineaments were identified from Digital Elevation Model (DEM). DEM of study area were provided as DEMNAS published by Indonesian Geospatial Agency. DEMNAS has spatial resolution of 0.27 arc second. Lineaments layer usually is converted into measurable quantity such as density 363738 . However, in this study lineaments were conventionally assigned and classified following their capacity to promote groundwater occurrence. This approach was performed in Groundwater Potentiality Index ${ }^{47}$. This approach for lineaments is suitable for hard rock geology condition where groundwater occurrence is mainly governed by fractures.

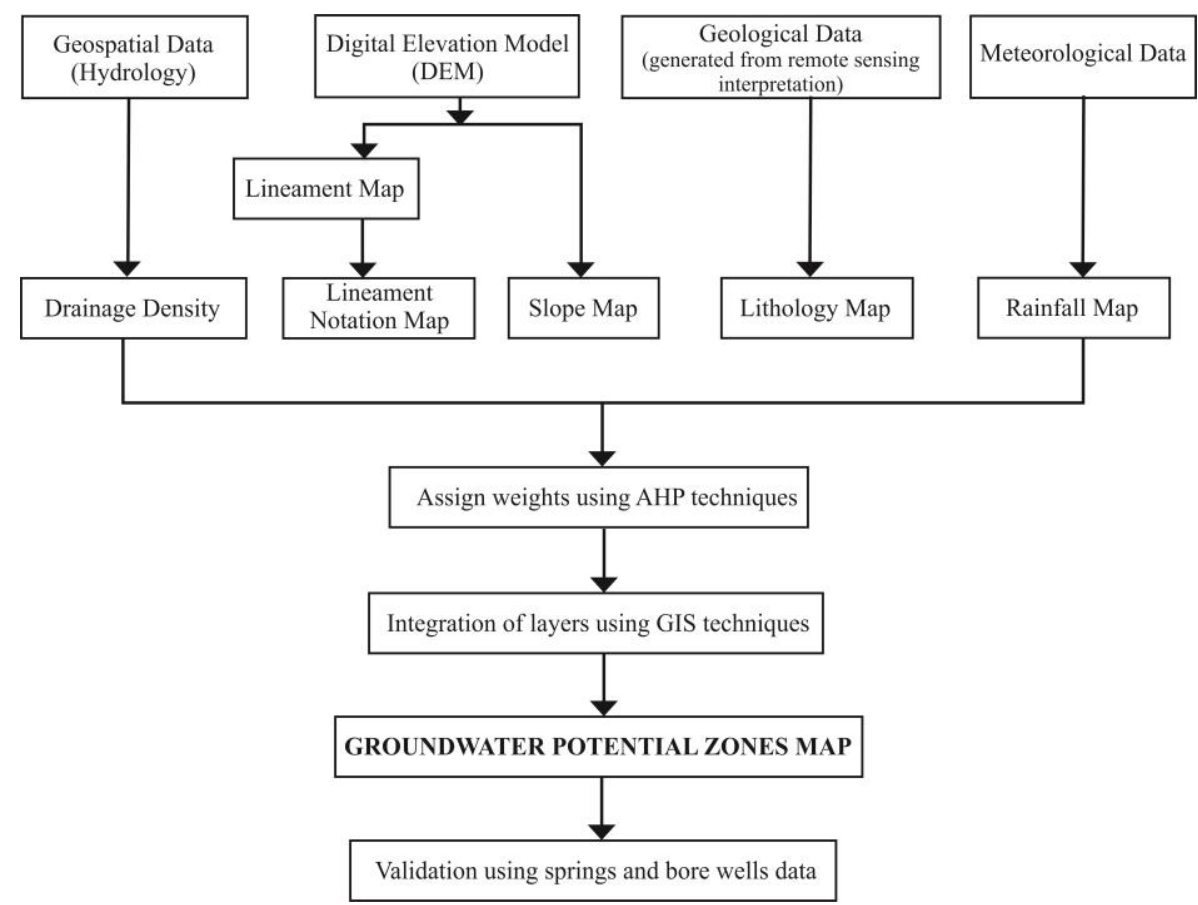

Figure 2. Flow chart of the methods for estimate the groundwater potential of the study area

Slope is principal factor of the superficial water flow since it govern the effect of gravity on the water movement ${ }^{47}$. Slope map was generated from DEMNAS data using tools in ArcGIS 10.4. Then, slope map was presented in degree units. Rainfall data in study area was provided by BPS-Statistics of Banjarnegara. Rainfall is the main source of groundwater recharge ${ }^{29} 48$. It determines the amount of water which would percolate into the groundwater system ${ }^{50}$.

The lithology influences both the permeability of the aquifer rocks and the distribution of the fracture pattern ${ }^{47}$. Lithology map in this study was based on geological map in the scale of 1:50,000. The maps were published by Geological Survey Center of Indonesia. Those geological map were generated from remote sensing interpretation using several basic data including IFSAR, RADARSAT2, TERRASAR X, SRTM $30 \mathrm{~m}$ and 90 m; LANDSAT V and ETM +7; ASTER, ALOS (AVNIR), regional geology map and topographic map. 
Basic data of drainage was available as hydrography layer which was provided by Indonesian Geospatial Agency. Drainage was processed as density. The drainage density is the ratio of the sum of the lengths of streams to the area of the grid 294950 . Drainage density was calculated using grid size of $8.5 \mathrm{~km}^{2}$ through the equation 1 . This analysis was performed based on analysis which was conducted by Mohammadi-Behzad (2018) ${ }^{39}$. Where, $\sum \mathrm{D}_{i}$ is the total length of all streams $i(\mathrm{~km})$ and A is the area of the grid $\left(\mathrm{km}^{2}\right)^{39}$. The values obtained for each grid were plotted at the center of the grid, then drainage density map is produced for the area by kriging interpolation technique ${ }^{39}$.

$$
\operatorname{Dd}=\sum_{i=1}^{i=n} \frac{D_{i}}{A}\left(\mathrm{~km}^{-1}\right)
$$

\subsection{Analytic Hierarchy Process}

First step of AHP method is to assign the level of importance of each factors based on Saaty's scale values. Consequently, all factors are compared in a pairwise comparison matrix. The weight which was assigned to different thematic layers were normalized using Saaty's AHP techniques. To control and test the consistency and judgement of the assigned weights, Consistency Ratio (CR) is calculated. First step to calculate CR is to compute maximum eigenvalue $\left(\lambda_{\max }\right)$. Then, calculate the Consistency Index (CI) using equation 2, where $\mathrm{n}$ is number of factors. CR is resulted by dividing CI by RI (Ratio Index). The value of RI is given based on Saaty's 1-9 scale. If the value of CR is less than 0.1, the judgement of weights is acceptable and consistent.

$$
\begin{aligned}
& \mathrm{CI}=\frac{\lambda \max -\mathrm{n}}{\mathrm{n}-1} \\
& \mathrm{CR}=\frac{\mathrm{CI}}{\mathrm{RI}}
\end{aligned}
$$

\subsection{Overlay Analysis}

All five thematic layer maps were integrated using ArcGIS 10.4 as a summation of overall groundwater influencing factors to produce the groundwater potential map (GPM) of study area. The following formula was used to estimate the groundwater potential map ${ }^{1851} 52$.

$$
\mathrm{GPM}=(\mathrm{MC} 1 \mathrm{w} \times \mathrm{SC} 1 \mathrm{r})+(\mathrm{MC} 2 \mathrm{w} \times \mathrm{SC} 2 \mathrm{r})+(\mathrm{MC} 3 \mathrm{w} \times \mathrm{SC} 3 \mathrm{r})+(\mathrm{MC} 4 \mathrm{w} \times \mathrm{SC} 4 \mathrm{r})+(\mathrm{MC} 5 \mathrm{w} \times \mathrm{SC} 5 \mathrm{r})
$$

where GPM is groundwater potential map, MC1-MC5 is the main criteria (1-5 thematic layer map), w is the weight of the thematic map, SC1-SC5 is the sub-criteria of each thematic layer map and $\mathrm{r}$ is the sub-criteria class ranking.

\section{RESULTS AND DISCUSSION}

\subsection{Weights and Classes of Layers}

The weights for each factors were decided based on the local field experience and expert opinions. The comparison of importance level of all five thematic layers are shown in a pairwise comparison matrix (Table 1). Normalized weight is presented in Table 2. Based on calculation, Consistency Ratio (CR) of this research is 0.0095 which mean that the judgement of the pairwise comparison matrix is consistent. Hence, the assigned weight for lineament, slope, rainfall, lithology, and drainage are $0.3892,0.2141,0.1987,0.1213$, and 0.0767 respectively. Ranks was assigned to different class of the individual themes are presented in Table 3. The thematic maps for all layers are presented in Figure 3.

Table 1. Pairwise comparison matrix for AHP processing

\begin{tabular}{lccccc}
\hline \multicolumn{1}{c}{ Factors } & Lineament & Slope & Rainfall & Lithology & Drainage \\
\hline Lineament & 1 & 2 & 2 & 3 & 5 \\
Slope & $1 / 2$ & 1 & 1 & 2 & 3 \\
Rainfall & $1 / 2$ & 1 & 1 & 2 & 2 \\
Lithology & $1 / 3$ & $1 / 2$ & $1 / 2$ & 1 & 2 \\
Drainage & $1 / 5$ & $1 / 3$ & $1 / 2$ & $1 / 2$ & 1 \\
\hline Column Total & 2.53 & 4.83 & 5 & 8.50 & 13 \\
\hline
\end{tabular}


Table 2. Normalized weights for thematic layers

\begin{tabular}{lcccccc}
\hline \multicolumn{1}{c}{ Factors } & Lineament & Slope & Rainfall & Lithology & Drainage & $\begin{array}{c}\text { Normalized } \\
\text { Weight }\end{array}$ \\
\hline Lineament & 0.39 & 0.41 & 0.40 & 0.35 & 0.38 & 0.3892 \\
Slope & 0.20 & 0.21 & 0.20 & 0.24 & 0.23 & 0.2141 \\
Rainfall & 0.20 & 0.21 & 0.20 & 0.24 & 0.15 & 0.1987 \\
Lithology & 0.13 & 0.10 & 0.10 & 0.12 & 0.15 & 0.1213 \\
Drainage & 0.08 & 0.07 & 0.10 & 0.06 & 0.08 & 0.0767 \\
\hline Column Total & 1.00 & 1.00 & 1.00 & 1.00 & 1.00 & 1.00 \\
\hline
\end{tabular}

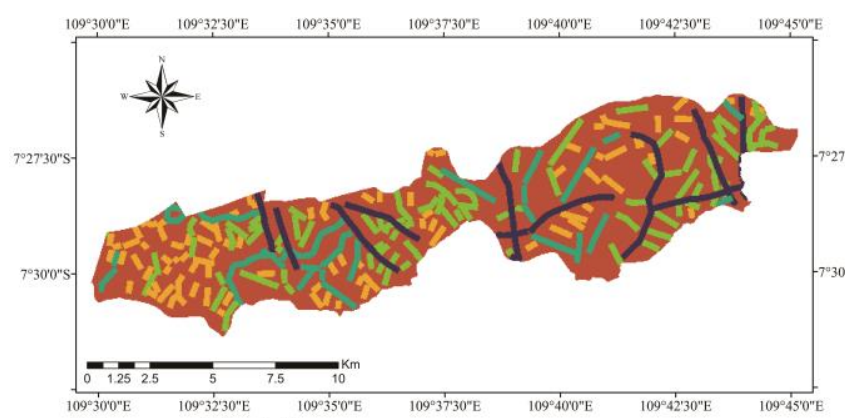

Lineament Notation
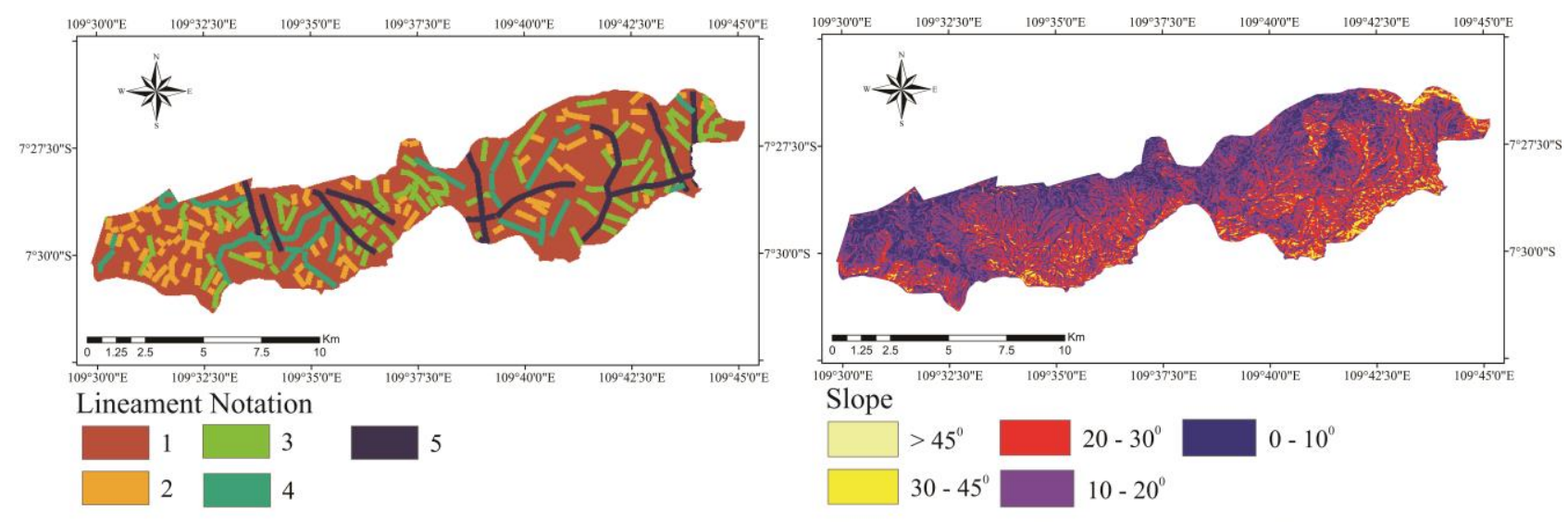

Slope
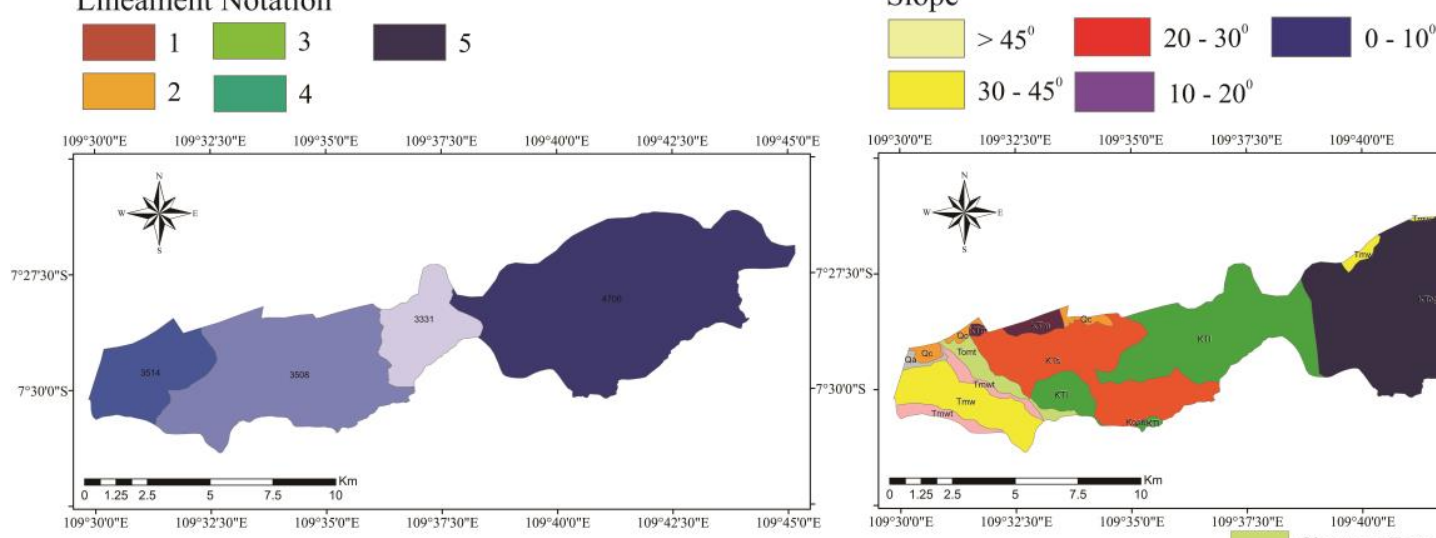

Rainfall
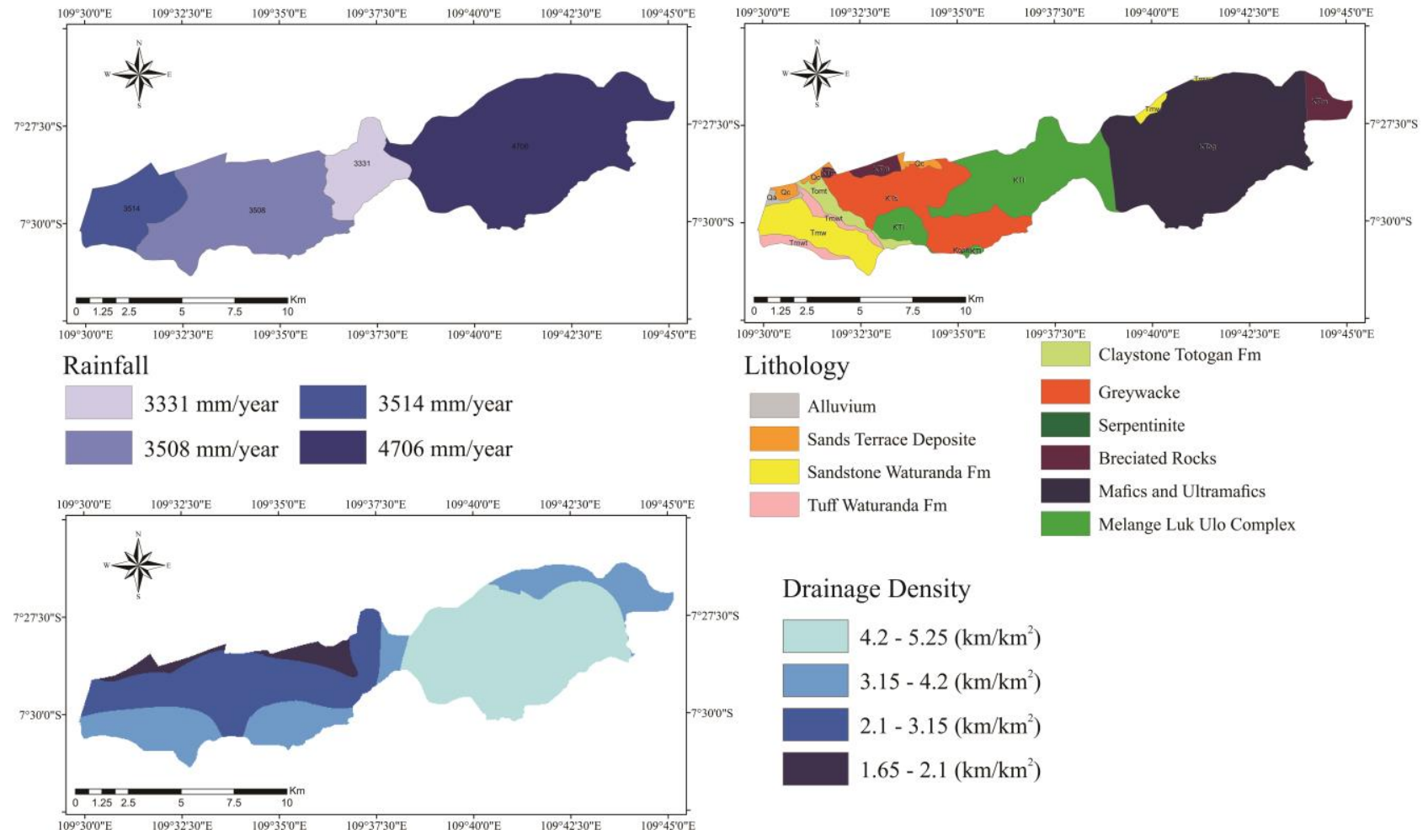

Drainage Density

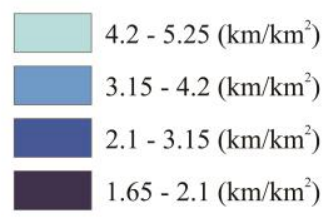

Figure 3. All five thematic maps and its classes 
Table 3. Assigned rank for various classes of all thematic layers

\begin{tabular}{|c|c|c|c|c|}
\hline Factors & Weight & Class & $\begin{array}{l}\text { Groundwater } \\
\text { storage potential }\end{array}$ & $\begin{array}{l}\text { Assigned } \\
\text { Rank }\end{array}$ \\
\hline \multirow{5}{*}{ Lineament } & \multirow{5}{*}{0.3892} & No lineament & Very Low & 1 \\
\hline & & Fractures, short lineament & Low & 2 \\
\hline & & $\begin{array}{l}\text { Local faults, frequent } \\
\text { fractures }\end{array}$ & Moderate & 3 \\
\hline & & $\begin{array}{l}\text { Interconnected local } \\
\text { faults, frequent faults }\end{array}$ & High & 4 \\
\hline & & Major long faults & Very High & 5 \\
\hline \multirow{5}{*}{ Slope } & \multirow{5}{*}{0.2141} & $>45^{0}$ & Very Low & 1 \\
\hline & & $30^{0}-45^{0}$ & Low & 2 \\
\hline & & $20^{0}-30^{0}$ & Moderate & 3 \\
\hline & & $10^{0}-20^{0}$ & High & 4 \\
\hline & & $0^{0}-10^{0}$ & Very High & 5 \\
\hline \multirow{2}{*}{ Rainfall } & \multirow{2}{*}{0.1987} & $3000-4000 \mathrm{~mm} /$ year & High & 4 \\
\hline & & $4000-5000 \mathrm{~mm} /$ year & Very High & 5 \\
\hline \multirow{5}{*}{ Lithology } & \multirow{5}{*}{0.1213} & $\begin{array}{l}\text { Mélange Luk Ulo } \\
\text { Complex, Serpentinite, } \\
\text { Mafic and Ultramafic and } \\
\text { Brecciated Rocks }\end{array}$ & Very Low & 1 \\
\hline & & $\begin{array}{l}\text { Claystone Totogan Fm } \\
\text { Tuff Waturanda Fm }\end{array}$ & Low & 2 \\
\hline & & Greywacke & Moderate & 3 \\
\hline & & Sandstone Waturanda Fm & High & 4 \\
\hline & & $\begin{array}{l}\text { Quaternary Terrace } \\
\text { Deposit } \\
\text { Alluvium }\end{array}$ & Very High & 5 \\
\hline \multirow{4}{*}{ Drainage } & \multirow{4}{*}{0.0767} & $4.2-5.25 \mathrm{~km} / \mathrm{km}^{2}$ & Very Low & 1 \\
\hline & & $3.15-4.2 \mathrm{~km} / \mathrm{km}^{2}$ & Low & 2 \\
\hline & & $2.1-3.15 \mathrm{~km} / \mathrm{km}^{2}$ & Moderate & 3 \\
\hline & & $1.65-2.1 \mathrm{~km} / \mathrm{km}^{2}$ & High & 4 \\
\hline
\end{tabular}

221 lineaments were identified from DEM data. Then, all lineaments were processed using buffer tools with the total width of 250 meters. Buffering of 250 meters width was conducted based on background fracturing zone according to fault zone model by Braathen \& Gabrielsen (2000) ${ }^{53}$. Each lineament buffer zone was given a rank of 1-5 based on interpretation of its capacity to promote groundwater occurrence. Major long faults were given the highest rank of 5 . Interconnected local faults and frequents faults were attributed with rank of 4 . Local faults and frequent fractures were given the moderate rank. While, fractures and short lineaments were attributed with rank of 2 as they were believed as low groundwater storage potential. Lastly, area of no lineament were given the lowest rank of 1 .

Slope of study area was classified into 5 classes as $0^{\circ}-10^{0}, 10^{\circ}-20^{\circ}, 20^{\circ}-30^{\circ}, 30^{\circ}-45^{\circ}$, and $>45^{\circ}$. Groundwater potential occurred in gentle slope to plain region as water flow is slow and the time is enough available to improve the infiltration of water to the underlying fractured aquifer ${ }^{47}$. Therefore, lower degree of slope was given higher rank than higher degree of slope. Slope of $0^{0}-10^{0}$ was given the highest rank of 5 . Whereas, slope of more than $45^{0}$ was given the lowest rank of 1 .

Rainfall data of study area was obtained from BPS-Statistics of Banjarnegara. There are several limitation of rainfall of study area as follows (1) the location of rainfall station were unknown, (2) rainfall data were attributed based on administrative area of the sub-district, (3) only one of 4 sub-district which has complete annual rainfall data from the year of 2007 until 2016. There are 4 sub-district in the study area, Pagedongan sub-district which is located in the easternmost of the study area, Mandiraja sub-district which is located in the westernmost of the study area, Bawang subdistrict which in the mid east, and Purwanegara sub-district which is located in the mid west. Pagedongan sub-district has average of annual rainfall of $4706 \mathrm{~mm} /$ year. Average of annual rainfall of $3331 \mathrm{~mm} / \mathrm{year}$ was recorded in the Bawang sub-district. While, Purwanegara sub-district has average of annual rainfall of $3508 \mathrm{~mm} /$ year. Lastly, Mandiraja subdistrict has average of annual rainfall of $3514 \mathrm{~mm} /$ year. Rainfall was classified into 2 classes, 3000-4000 mm/year which 
is given rank of 4 , and $4000-5000 \mathrm{~mm} /$ year which is attributed with rank of 5 as expected to have highest groundwater potential.

Melange Luk Ulo Complex, Serpentinite, Mafic and Ultramafic, and Brecciated Rocks which were consisted of metamorphic and igneous rocks were attributed as the lowest groundwater potential due to lower permeability. Claystone Totogan Formation and Tuff Waturanda Formation were given rank of 2. Greywacke as the member of Luk Ulo Complex was given moderate rank of 3. While, Sandstone Waturanda Formation was attributed with rank of 4 . The highest rank was assigned to Quaternary Terrace Deposits and Alluvium.

Drainage density of the study area ranging from $1.65 \mathrm{~km} / \mathrm{km} 2$ to $5.23 \mathrm{~km} / \mathrm{km}^{2}$. Therefore, drainage density of the study are was classified into 4 classes: 1.65-2.1, 2.1-3.15, 3.15-4.2, and 4.2-5.25 km/ $\mathrm{km}^{2}$ as shown in Figure 3. The highest drainage density appeared in the eastern part of the study area. Higher drainage density were given lower rank, while lower drainage density were given higher rank. Hence, $4.2-5.25 \mathrm{~km} / \mathrm{km}^{2}$ was given the lowest rank of 1. Whilst, 1.65-2.1 $\mathrm{km} / \mathrm{km}^{2}$ was given rank of 4 .

\subsection{Groundwater Potential Zones Map}

The systematic AHP analysis on weighted factors generated a groundwater potential zones map using raster calculator tool in ArcGIS software by integrating all thematic maps. The index of groundwater potential is ranging from 1.79 to 4.72. The classification of groundwater potential zone is based on equal interval method. Hence, the interval of 1-1.8, 1.8-2.6, 2.6-3.4, 3.4-4.2, and 4.2-5.00 is assigned to very low, low, moderate, high, and very high. Groundwater potential zones map is presented in Figure 4.

The groundwater potential zone at a glance is highly reflects lineament layer map. Almost to none of the study area is classified as very low groundwater potential zone. This class only covered a pixel which equivalent to area of $1529 \mathrm{~m}^{2}$. The study revealed that $43.02 \%\left(37.12 \mathrm{~km}^{2}\right)$ of the study area exhibits poor groundwater potential zones (Table 4). Poor groundwater potential zone is the largest index in the study area. Poor groundwater potential zone is characterized by having no lineament zone, slope more than $20^{\circ}$, lithology Melange Luk Ulo Complex, Serpentinite, Mafic and Ultramafic, Brecciated Rocks, Claystone Totogan Formation, and Tuff Waturanda Formation; and higher drainage density. Those rock assemblages consist of metamorphic rocks (amphibolite, serpentinite, schist and phyllite), igneous rock (granite, porphyry, gabbro, and basalt), and sedimentary rocks such as tuff, claystone, and shale.

$17.98 \%\left(15.52 \mathrm{~km}^{2}\right)$ of the study area was classified as having high to very high groundwater potential zones. While moderate groundwater potential zone covered $38.99 \%\left(33.65 \mathrm{~km}^{2}\right)$ of the study area. The presence of high to very high groundwater potential zone may pertain to the presence of interconnected local faults, frequent faults, and major long faults; greywacke, alluvium and quaternary unconsolidated terrace deposit, higher rainfall, gentle slope below $20^{\circ}$, and lower drainage density.

Table 4. Classification of groundwater potential zone

\begin{tabular}{lcc}
\hline Groundwater Potential Zones & Area $(\%)$ & Area \\
\hline Very High & 1.18 & $1.02 \mathrm{~km}^{2}$ \\
High & 16.80 & $14.49 \mathrm{~km}^{2}$ \\
Moderate & 38.99 & $33.65 \mathrm{~km}^{2}$ \\
Low & 43.02 & $37.12 \mathrm{~km}^{2}$ \\
Very Low & 0.00 & $1529 \mathrm{~m}^{2}$ \\
\hline Total & 1.00 & 115.89 \\
\hline
\end{tabular}




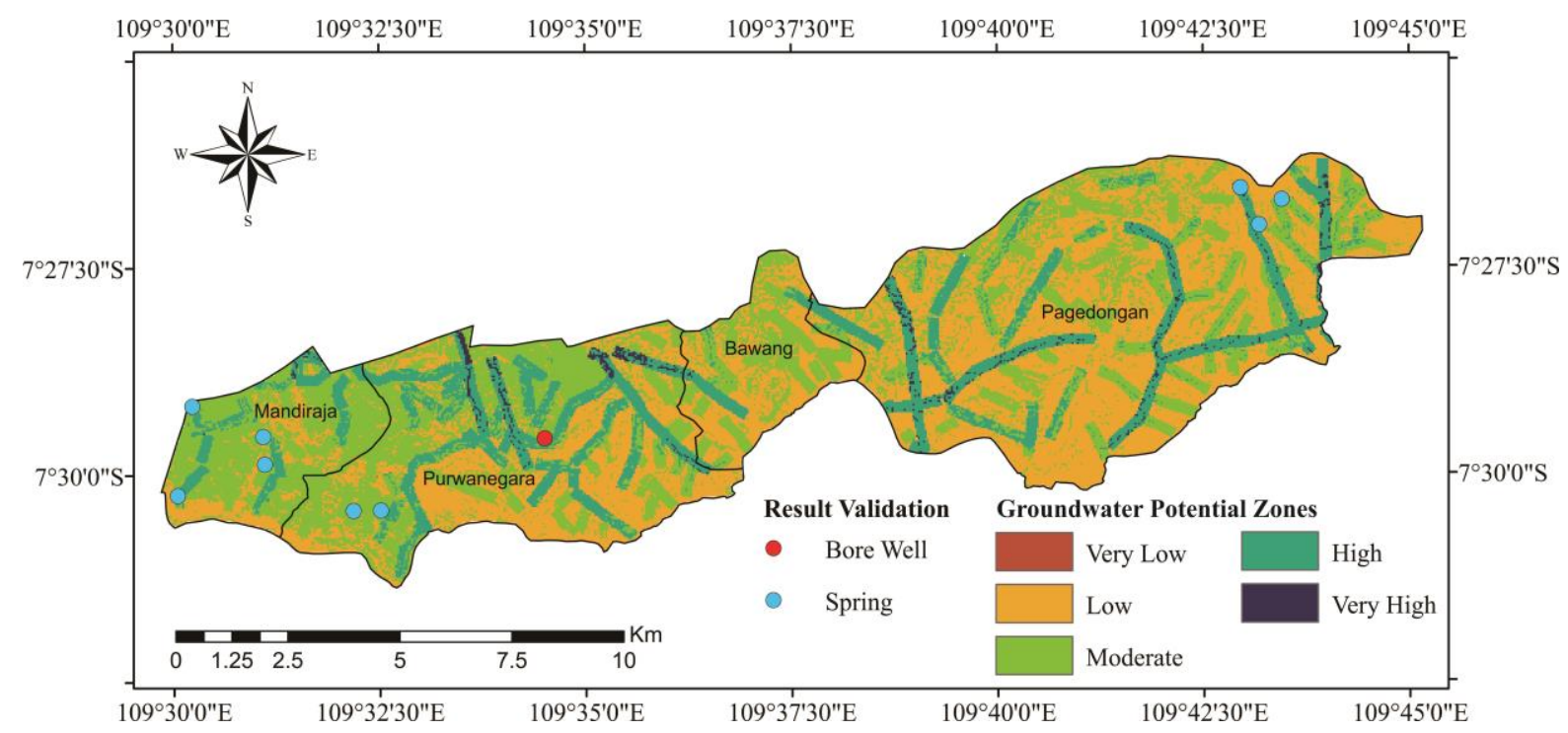

Figure 4. Groundwater potential zones map

\subsection{Result Validation}

The occurrence and discharge of springs and bore wells were used for validation of groundwater potential map. Firstly, there are 52 springs and 2 bore wells in the study area which were discovered during the observation in the dry season of 2018. However, there are only 9 springs and 1 bore wells where appropriate measurement of discharge were conducted. The discharge of springs and bore wells ranging from $0.12 \mathrm{l} / \mathrm{s}$ to $2 \mathrm{l} / \mathrm{s}$. This range of springs discharge is classified as sixth magnitude springs based on classification of springs by discharge according to Meinzer ${ }^{53}$. While, bore well yield of 2 l/s.

Based solely on the occurrence of springs and bore wells, 1 spring and 1 bore well are located in very high GPZ, 9 springs and 1 bore well in high GPZ, 30 springs in moderate GPZ, and 12 springs in low GPZ. While, no spring in very low GPZ. 30 springs are located in lineament zone. Apparently, high to very high GPZ and occurrence of springs correspond to lineaments.

The correlation of AHP raster values to the corresponding discharge of springs and bore wells showed a positive coefficient of determination $\left(\mathrm{R}^{2}\right)$ of 0.80 (Figure 5). It shows that the groundwater potential zones map which was generated by using integration of RS, GIS, and AHP technique in the research area have a promising result.

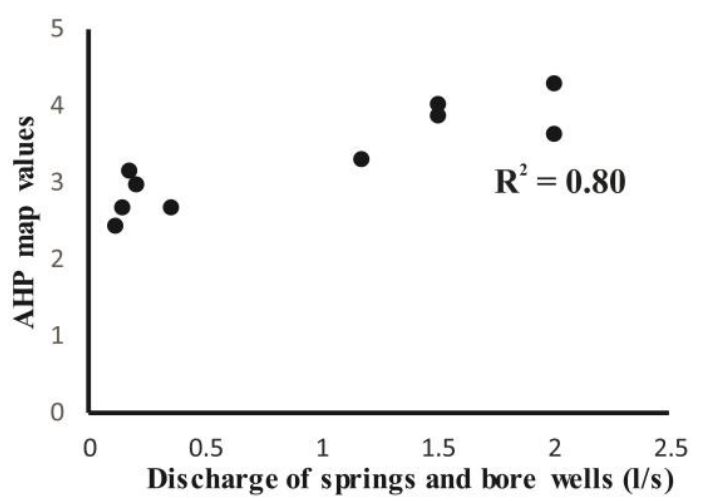

Figure 5. Plot of the AHP raster value to the corresponding discharge of springs and bore wells 


\section{CONCLUSIONS}

The application of remote sensing, GIS, AHP is demonstrated as useful tools and cost effective method for delineation of groundwater potential zones. Groundwater in the study area is mainly controlled by lineament, slope, rainfall, and lithology factors. While, drainage is the secondary factors. Groundwater potential in the study area is classified into five: very low, low, moderate, high, and very high groundwater potentials cover $1529 \mathrm{~m}^{2}(0.00 \%), 37.12 \mathrm{~km}^{2}(43.02 \%), 33.65$ $\mathrm{km}^{2}$ (38.99\%), $14.49 \mathrm{~km}^{2}(16.80 \%)$, and $1.02 \mathrm{~km}^{2}$ (1.18\%) of study area respectively. High to very high GPZ are characterized by the presence of interconnected local faults, frequent faults, and major long faults; greywacke, alluvium and quaternary unconsolidated terrace deposit, higher rainfall, gentle slope below $20^{\circ}$. Evaluation using discharge of springs and bore wells denoted that the result of groundwater potential zones map is promising as the coefficient of determination $\left(\mathrm{R}^{2}\right)$ of 0.80 . This GPZ map can be a guide and basis information for local authorities and planners about the favorable area for prospective exploration of groundwater.

\section{ACKNOWLEDGEMENT}

The authors sincerely acknowledge "Agency of Planning, Research and Development of Banjarnegara Regency" and "PAMSIMAS Banjarnegara" for their kind and generous support in presenting needed data and maps. The authors also would like to express gratitude to Thema Arrisaldi and Raja Susatio in supporting maps and assisting the GIS processing.

\section{REFERENCES}

[1] Hartono, U., “52 Desa di Banjarnegara Alami Kekeringan,” Detiknews, 15 August 2017, $<$ https://news.detik.com/berita-jawa-tengah/d-3600414/52-desa-di-banjarnegara-alami-kekeringan> (1 August 2018)

[2] Novit, E., "Kekeringan di Banjarnegara, 1000 Jiwa Mengalami Krisis Air Bersih," SINDOnews.com, 16 August 2017 <https://daerah.sindonews.com/read/1230801/22/kekeringan-di-banjarnegara-1000-jiwa-mengalamikrisis-air-bersih-1502841961> (1 August 2018)

[3] Fahmi, M. I., "Kekeringan Landa 25 Desa di Banjarnegara," Kompas, 1 September 2017 <https://regional.kompas.com/read/2017/09/01/14471921/kekeringan-landa-25-desa-di-banjarnegara> (1 August 2018)

[4] Dharmawan, L., "Bencana Kekeringan di Banjarnegara Kian Meluas," Media Indonesia, 20 August 2017 <https://mediaindonesia.com/read/detail/118498-bencana-kekeringan-di-banjarnegara-kian-meluas> (1 August 2018)

[5] Muzakki, K., "Kekeringan di Banjarnegara Meluas, 610 ribu liter Air Bersih Habis Tersalurkan," Tribun Jateng, 9 September 2017 <https://jateng.tribunnews.com/2017/09/09/kekeringan-di-banjarnegara-meluas-610-ribuliter-air-bersih-habis-tersalurkan> (1 August 2018)

[6] Novit, E., "Bencana Kekeringan, 18 ribu Warga Banjarnegara Mengais Air Bersih," OKEZONE news, 20 September 2017 <https://news.okezone.com/read/2017/09/20/512/1779291/bencana-kekeringan-18-ribu-wargabanjarnegara-mengais-air-bersih> (1 August 2018)

[7] Nurrohmah, H. and Nurjani, E., "Kajian Kekeringan Meteorologis Menggunakan Standardized Precipitation Index (SPI) di Provinsi Jawa Tengah," Geomedia. Papers 15, 1-15 (2017).

[8] Effendi, A.T., [Peta Hidrogeologi Indonesia Lembar VI Pekalongan (Jawa) Skala 1:250.000], Direktorat Geologi Tata Lingkungan, Bandung, 1 (1985).

[9] Asikin, S., Handoyo, A., Busono, H. and Gafoer, S., [Peta Geologi Lembar Kebumen, Jawa, Skala 1:100.000], Pusat Penelitian dan Pengembangan Geologi, Bandung, 1 (1992).

[10] Condon, W. H., Pardyanto, L., Ketner, K. B., Amin, T. C., Gafoer, S. and Samodra, H., [Peta Geologi Lembar Banjarnegara dan Pekalongan, Jawa, Skala 1:100.000], Pusat Penelitian dan Pengembangan Geologi, Bandung, 1 (1996).

[11] Dinas Energi dan Sumber Daya Mineral, [Peta Cekungan Air Tanah di Provinsi Jawa Tengah], Dinas ESDM Provinsi Jawa Tengah, Semarang, 1 (2011).

[12] Anonim, [Kecamatan Pagedongan Dalam Angka 2017], Badan Pusat Statistik Kabupaten Banjarnegara, Banjarnegara, 72 (2017). 
[13] Sumanto, [Kecamatan Mandiraja Dalam Angka 2017], Badan Pusat Statistik Kabupaten Banjarnegara, Banjarnegara, 119 (2017).

[14] Sustrianto, [Kecamatan Bawang Dalam Angka 2017], Badan Pusat Statistik Kabupaten Banjarnegara, Banjarnegara, 104 (2017).

[15] Windiatmoko, [Kecamatan Purwanegara Dalam Angka 2017], Badan Pusat Statistik Kabupaten Banjarnegara, Banjarnegara, 86 (2017).

[16] Rao, Y.S. and Jugran, D.K., "Delineation of groundwater potential zones and zones of groundwater quality suitable for domestic purposes using remote sensing and GIS," Hydrology Science Journal. Papers 48(5), 821833 (2003).

[17] Jha, M. K., Chowdhury, A., Chowdary, V. M. and Peiffer, S., "Groundwater management and development by integrated remote sensing and geographic information systems: prospects and constraints," Water Resource Management. Papers 21(2), 427-467 (2007).

[18] Prasad, R. K., Mondal, N. C., Banerjee, P., Kumar, M. V. N. and Singh, V. S., "Deciphering potential groundwater zone in hard rock through the application of GIS," Environmental Geology. Papers 55(3), 467-475 (2008).

[19] Pradhan, B., "Groundwater potential zonation for basaltic watersheds using satellite remote sensing data and GIS techniques," Central European Journal of Geosciences. Papers 1(1), 120-129 (2009).

[20] Arkoprovo, B., Adarsa, J. and Prakash, S. S., "Delineation of groundwater potential zones using satellite remote sensing and geographic information techniques: a case study from Ganjam district, Orissa, India," Research Journal of Recent Sciences. Papers 1(9), 59-66 (2012).

[21] Nampak, H., Pradhan, B. and Manap, M. A., "Application of GIS based data driven evidential belief function model to predict groundwater potential zonation," Journal of Hydrology. Papers 513, 283-300 (2014).

[22] Rahmati, O., Samani A. N., Mahdavi, M., Pourghasemi, H. R. and Zeinivand, H., "Groundwater potential mapping at Kurdistan region of Iran using analytic hierarchy process and GIS," Arabian Journal of Geosciences. Papers 8(9), 7059-7071 (2014).

[23] Moghaddam, D. D., Rezaei, M., Pourghasemi, H. R., Pourtaghie, Z. S. and Pradhan, B., "Groundwater spring potential mapping using bivariate statistical model and GIS in the Taleghan watershed, Iran," Arabian Journal of Geosciences. Papers 8(2), 913-929 (2015).

[24] Srinivasa, Y. and Jugran, D., "Delineation of groundwater potential zones and zones of groundwater quality suitable for domestic purposes using remote sensing and GIS," Journal-des Sciences Hydrologiques. Papers 48(5), 821-833 (2003).

[25] Al Saud, M., "Mapping potential areas for groundwater storage in Wadi Aurnah basin, western Arabian peninsula, using remote sensing and geographic information system techniques," Hydrogeology Journal. Papers $18,1481-1495$ (2010).

[26] Dar, I., Sankar, K. and Dar, M., "Remote sensing technology and geographic information system modeling: an integrated approach towards the mapping of groundwater potential zones in hardrock terrain, Mamundiyar basin," Journal of Hydrology. Papers (394), 285-295 (2010).

[27] Elewa, H. and Qaddah, A., "Groundwater potentiality mapping in the sinai peninsula, Egypt, using remote sensing and GIS-watershed based modeling," Hydrogeology Journal. Papers 19, 613-628 (2011).

[28] Mayilvaganan, M., Mohana, P. and Naidu, K., "Delineating groundwater potential zones in Thurinjapuram watershed using geospatial techniques," Indian Journal of Science and Technology. Papers 4(11), 1470-1476 (2011).

[29] Magesh, N., Chandrasekhar, N. and Soundranayagam, J., "Delineation of groundwater potential zones in Theni district, Tamil Nadu, using remote sensing, GIS and MIF techniques," Geoscience Frontiers. Papers 3(2), 189196 (2012).

[30] Srivastava, V., Giri, D. and Bharadwaj, P., "Study and mapping of ground water prospect using remote sensing, GIS and geoelectrical resistivity techniques: a case study of Dhanbad district, Jharkhand, India," Journal of Indian Geophysical Union. Papers 16(2), 55-63 (2012).

[31] Satapathy, I. and Syeh, T. H., "Characterization of groundwater potential and artificial recharge sites in Bokaro District, Jharkhand (India), using remote sensing and GIS-based techniques," Environmental Earth Science. Papers 74, 4215 - 4232 (2015).

[32] Ismail, E., El-Sayed, E., Sakr, S. and Youssef, E., "Characteristic of groundwater potentialities in West Nile Valley South, Minia Governorate, Egypt," Arabian Journal of Geoscience. Papers 10, 520 - 531 (2017). 
[33] Saha, S., "Groundwater potential mapping using analytical hierarchical process: a study on Md. Bazar Block of Birbhum District, West Bengal," Spatial Information Research. Papers 25, 615 - 626 (2017).

[34] Saaty, T. L. and Vargas, L. G., [Models, methods, concepts \& applications of the analytic hierarchy process], Kluwer Academic Publisher, Boston, 333 (2001).

[35] Saaty, T. L., "Decision making with the analytic hierarchy process," International Journal of Services Sciences. Papers 1(1), 83-98 (2008).

[36] Agarwal, R. and Garg, P., "Remote sensing and GIS based groundwater potential and recharge zones mapping using multi-criteria decision making technique," Water Resources Management. Papers 30, 243-260 (2016).

[37] Panahi, M. R., Mousavi, S. M. and Rahimzadegan, M., "Delineation of groundwater potential zones using remote sensing, GIS, and AHP technique in Tehran-Karaj plain, Iran," Environmental Earth Science. Papers 76, 792-806 (2017).

[38] Pinto, D., Shrestha, S., Babel, M. S. and Ninsawat, S., "Delineation of groundwater potential zones in the Comoro watershed, Timor Leste using GIS, remote sensing and analytic hierarchy process (AHP) technique," Applied Water Science. Papers 7, 503-519 (2017).

[39] Mohammadi-Behzad, H. R., Charchi, A., Kalantari, N., Nejad, A. M. and Vardanjani, H, K., "Delineation of groundwater potential zones using remote sensing (RS), geographical information system (GIS) and analytic hierarchy process (AHP) techniques: a case study in the Leylia-Keynow watershed, southwest of Iran," Carbonates Evaporites. 1-13 (2018).

[40] Van Bemmelen, R. W., [The Geology of Indonesia, Vol. IA, General Geology of Indonesia and Adjacent Archipelagoes], Martinus Nyhoff The Haque, Netherland, 732 (1949)

[41] Sidarto, [Peta Geologi Hasil Interpretasi Citra Inderaan Jauh Banjarnegara, Jawa Tengah, Skala 1:50.000], Badan Geologi, Bandung, 1 (2013).

[42] Sidarto, [Peta Geologi Hasil Interpretasi Citra Inderaan Jauh Kebumen, Jawa Tengah, Skala 1:50.000], Badan Geologi, Bandung, 1 (2013).

[43] Pulunggono, A. and Martodjojo, S., [Perubahan tektonik Paleogen-Neogen merupakan peristiwa tektonik penting di Jawa, Kumpulan Makalah Seminar Geologi dan Geotektonik Pulau Jawa sejak Akhir Mesozoik hingga Kuarter], Jurusan Teknik Geologi Universitas Gadjah Mada, Yogyakarta, 1 - 14 (1994).

[44] Wakita, K., Munasri, and Bambang, W., "Cretacious radiolarians from the Luk-Ulo Melange Complex in the Karangsambung area, Central Java, Indonesia," Journal of South East Asian Earth Sciences. Papers 9(1/2), 2943 (1994).

[45] Satyana, A. H., "Structural Indentation of Central Java: A Regional Wrench Segmentation," Proc. Joint Convention, 193 - 204 (2005).

[46] Singhal, B. B. S. and Gupta, R. P., [Applied Hydrogeology of Fractured Rocks, Second Edition], Springer, Dordrecht Heidelberg London New York, 408 (2010).

[47] Ettazarini, S., "Groundwater potentiality index: a strategically conceived tool for water research in fractured aquifers," Environmental Geology. Papers 52, 477-487 (2007).

[48] Shekhar, S. and Pandey, A. C., "Delineation of groundwater potential zone in hard rock terrain of India using remote sensing, geographical information system (GIS) and analytic hierarchy process (AHP) techniques," Geocarto International. Papers 30(4), 402-442 (2014).

[49] Adiat, K. A. N., Nawawi, M. N. M. and Abdullah, K., "Assessing the accuracy of GIS-based elementary multi criteria decision analysis as a spatial prediction tool-A case of predicting potential zones of sustainable groundwater resources," Journal of Hydrology. 440-441, 75-89 (2012).

[50] Mogaji, K. A., Lim, H. S. and Abdullah, K., "Regional prediction of groundwater potential mapping in a multifaceted geology terrain using GIS-based Dempster-Shafer model," Arabian Journal of Geosciences. Papers 8(5), 3235-3258 (2014).

[51] Muheeb, M. A., and Rasheed, A. J., "Evaluation of aquifers vulnerability to contamination in the Yarmouk river watershed, Jordan, based on DRASTIC method," Arabian Journal of Geosciences. Papers 3, 273-282 (2009).

[52] Kumar, T., Gautam, A. K. and Kumar, T., "Appraising the accuracy of GIS multi-criteria decision making technique for delineation of groundwater potential zone," Water Resource Management. Papers 28, 4449-4466 (2014).

[53] Ganerød, G.V., [Applied structural geology - case studies of underground constructions and rockslides, Ph.D thesis], Department of Earth Science, University of Bergen, Norway, 210 (2008).

[54] Todd, D. K., and Mays, L. W., [Groundwater Hydrology, Third Edition], John Willey \& Sons, Inc., United States of America, 636 (2005). 